\title{
Peroxisome proliferator-activated receptor activating hypoglycemic effect of Gardenia jasminoides Ellis aqueous extract and improvement of insulin sensitivity in steroid induced insulin resistant rats
}

Ying-l Chen ${ }^{1}$, Yu-Wen Cheng ${ }^{2,3}$, Chung-Yuh Tzeng ${ }^{2,4}$, Yu-Chen Lee ${ }^{5}$, Yaw-Nan Chang ${ }^{6}$, Shih-Chieh Lee ${ }^{7}$, Chin-Chun Tsai ${ }^{8,9}$, Jaw-Chyun Chen ${ }^{10}$, Jason Tze-Cheng Tzen ${ }^{1 *}$ and Shih-Liang Chang ${ }^{5,10^{*}}$

\begin{abstract}
Background: The active components of Gardenia (Gardenia jasminoides Ellis, GJ) exhibit a hypoglycemic effect by improving insulin secretion and lowering plasma lipids. In the present study, we fed a water extract of gardenia to steroid-induced insulin-resistant (SIIR) rats and observed changes in signaling proteins in order to elucidate the mechanisms of the insulin-sensitizing effect of $G J$ and evaluate its possibility as an insulin-sensitizing agent.

Methods: Normal Wistar rats were randomly divided into a control group (i.e., saline) and experimental groups (GJ 100 and $200 \mathrm{mg} / \mathrm{kg}$ ). Blood samples were taken at 0, 30, and 60 min for plasma glucose assay in order to determine the optimal dose to induce the hypoglycemic effect. SIIR rats were then randomly divided into a control group (i.e., saline) and an experimental group (optimal dose of gardenia extract) to observe the insulin-sensitizing effect of the extract. Finally, western blot analysis was performed to detect intracellular signaling proteins to elucidate the mechanisms of the insulin-sensitization effect of GJ.
\end{abstract}

Results: The normal Wistar rats in the GJ $200 \mathrm{mg} / \mathrm{kg}$ group exhibited significant hypoglycemic activity. Meanwhile, the SIIR rats had higher plasma glucose levels than normal rats. There was no obvious change in insulin level, but the insulin sensitivity index and homeostasis model assessment index were significantly elevated. Meanwhile, a significant hypoglycemic effect was observed with GJ $200 \mathrm{mg} / \mathrm{kg}$. In addition, intracellular signaling proteins including insulin receptor substrate-1 (IRS-1) and peroxisome proliferator-activated receptor (PPARY) were elevated in muscle cells.

Conclusions: The optimal dose of GJ aqueous extract of $200 \mathrm{mg} / \mathrm{kg}$ exerts a PPARY-activating hypoglycemic effect and improves insulin resistance in SIIR rats. Therefore, it is a potential insulin-sensitizing agent in type 2 diabetes mellitus with insulin resistance.

Keywords: Gardenia, Blood glucose, Insulin resistance, Peroxisome proliferator-activated receptor

\footnotetext{
*Correspondence: tctzen@dragon.nchu.edu.tw; slc0124@gmail.com

'Graduate Institute of Biotechnology, National Chung Hsing University,

Taichung, Taiwan

${ }^{5}$ Department of Acupuncture, China Medical University Hospital and School

of Chinese Medicine, China Medical University, Taichung, Taiwan

Full list of author information is available at the end of the article
} 


\section{Background}

Good control of blood glucose can effectively reduce the microvascular and macrovascular complications of diabetes mellitus (DM). Lifestyle modifications such as deceasing body weight, exercise, and diet control can decrease insulin resistance (IR). In turn, this can improve plasma glucose level and decrease the HbA1c level to $1 \%$ to $2 \%$ [1]. Unfortunately, most patients with DM only transiently maintain stable plasma glucose levels and ultimately require medication therapy.

The main targets of insulin are the muscle, liver, and adipose tissue; therefore, IR [2] induces abnormal glucose and lipid metabolism [3]. Several factors can induce IR, including decreased physical activity, high-fat diet, medications, and glucose intoxication. Some studies indicate that increased serum free fatty acid induces IR as well as obesity and type 2 DM $[4,5]$.

IR and inadequate insulin secretion are the main mechanisms of type $2 \mathrm{DM}$, but IR may manifest 5 to 10 years prior to DM development. Metabolic syndrome, which comprises IR, obesity, hyperlipidemia, and hypertension $[6,7]$, can increase the risk of cardiovascular disease by $79 \%$, especially large-vessel disease and DM $[8,9]$. According to the diagnostic criteria of the National Cholesterol Education Program Expert Panel, Adult Treatment Panel III, the incidence of metabolic syndrome is $23.9 \%$ [10]. There are several ways of improving IR, including diet modification, exercise, medication, acupuncture, and massage. Moreover, there are several categories of oral anti-diabetic agents, including $\alpha$-glycosidase inhibitors, biguanides, sulfonylureas, benzoic acid derivatives, phenylalanines, and thiazolidinediones [11-16]. Thiazolidinediones are specific anti-diabetic agents because they can modify genes regulating lipids and carbohydrates by activating peroxisome proliferatoractivated receptors (PPARs) $[17,18]$.

Gardenia jasminoides (GJ) has the potential to induce hypoglycemia and decrease serum lipid concentrations. One study reports that geniposide derived from GJ inhibits glucose phosphate and glucose-6-phosphatase activity, decreasing glycogenolysis and glucose release into the blood [19]. Ursolic acid, a component of GJ, can prevent diabetic complications by improving lipid metabolism and polyol pathways as well as inhibiting glycogenolysis. The active compounds of GJ are crocin [20], geniposide, and genipin. Several studies have confirmed that GJ protects liver function and has anti-inflammatory, hypoglycemic, and lipid-lowering effects [21].

IR usually progresses to DM over the course of several years [22]. Therefore, if IR can be successfully treated, DM should be preventable [23]. Thiazolidinediones are a type of oral anti-diabetes agent administered to improve IR. The first commercially available medicine in this category was troglitazone (Rezulin ${ }^{\circ}$ ), which was introduced in 1997 $[24,25]$. Some prospective studies confirmed that this drug decreases serum insulin level and preserves the insulin secretion function of islet cells. In addition, it can even prevent type 2 DM development [26,27]. However, it induces hepatotoxicity, which resulted in hepatic failure in some patients with diabetes, necessitating liver transplantation or even causing mortality; therefore, it was ultimately withdrawn from the market [28-30]. Rosiglitazone (Avandia ${ }^{\circ}$ ) and pioglitazone (Actos ${ }^{\odot}$ ) are the only thiazolidinediones currently available; their common hypoglycemic mechanism is the activation of PPAR $\gamma[31,32]$.

Our previous studies revealed that GJ has a hypoglycemic effect. In normal Wistar rats, GJ effectively induces insulin secretion and reduces blood glucose levels, simultaneously eliciting increases in insulin receptor substrate-1 (IRS-1) and PPARy signals. Therefore, cholinergic nerve activation is involved in the hypoglycemic mechanism of GJ. Rats with dexamethasone-induced type 2 diabetes do not have sufficient insulin. Therefore, the present study investigated whether aqueous extracts of GJ produce such hypoglycemic effects in rats with diabetes.

In order to evaluate the effects of hypoglycemia and improved IR, we administered GJ aqueous extracts to steroidinduced insulin-resistant (SIIR) rats. In addition, western blotting was used to evaluate intracellular signaling proteins to study the possible underlying mechanisms [33].

\section{Methods}

\section{Animal model}

Normal male Wistar rats weighing approximately 250$350 \mathrm{~g}$ and aged 8-10 weeks were purchased from the BioLASCO Animal Center, Taipei, Taiwan. SIIR rats were created by administrating dexamethasone $\left(1 \mathrm{mg} \cdot \mathrm{kg}^{-1} \cdot\right.$ day $^{-1}$ i.p. for 5 days) via the femoral vein in a fasting state [34,35]. Animals were housed in Plexiglas cages held at a room temperature of $25 \pm 2^{\circ} \mathrm{C}$ with a relative humidity of $60 \pm$ $5 \%$. Rats were fed standard rat chow and water ad libitum. Animals were randomly divided into experimental and control groups after a 1-week acclimation period. All animals were anesthetized using pentobarbital (40 mg/kg i.p.). All animals were treated in accordance with the National Institute of Health Guide for the Care and Use of Laboratory Animals, and the study protocol was approved by the ethics committee of the Da-Yeh University, Changhua, Taiwan.

\section{GJ aqueous extract}

GJ Ellis extract was provided by Challenge Bioproducts Co., Ltd. (Taiwan). The powder was mixed with normal saline to create a solution $(500 \mathrm{mg} / \mathrm{mL})$, which was stored at $4^{\circ} \mathrm{C}$.

\section{Plasma glucose assay}

Animals were anesthetized using pentobarbital $(40 \mathrm{mg} /$ $\mathrm{kg}$ i.p.). Approximately $0.3-0.5 \mathrm{~mL}$ blood was obtained from a femoral vein using a $1-\mathrm{mL}$ syringe containing 
heparin. Blood was obtained for glucose assay $30 \mathrm{~min}$ after treatment (baseline, $0 \mathrm{~min}$ ) and 30 and $60 \mathrm{~min}$ after baseline. The collected blood was placed into Eppendorf tubes, shaken lightly, and stored on ice. Following centrifugation at $21,880 \times g$ for $5 \mathrm{~min}$, Glucose UV reagent (Raichem, USA) was added to assay the amount of biological index glucose contained in the serum. The content was measured using a fully automatic biochemical analyzer (Roche COBAS-MIRA-PLUS, USA). Hypoglycemic activity (\%) was calculated as follows: [(glucose level at 30 or $60 \mathrm{~min}$-glucose level at baseline)/glucose level at baseline] $\times 100 \%$.

\section{Hypoglycemic effect measurement Optimal dose of GJ for the hypoglycemic effect}

Normal Wistar rats were separated randomly into 2 experimental groups: GJ 100 (oral feeding GJ, $100 \mathrm{mg} / \mathrm{kg}$ ) and GJ 200 (oral feeding GJ, $200 \mathrm{mg} / \mathrm{kg}$ ), and a control group (oral feeding normal saline). Each group consisted of 6 rats.

\section{Comparisons between normal Wistar and SIIR rats}

Normal Wistar rats were separated randomly into saline and SIIR groups ( $n=6$ each). The rats in the SIIR group were induced into SIIR by dexamethasone as described above. The same procedure was performed in the saline group, except saline was injected instead. Blood samples were taken at 0,30 , and $60 \mathrm{~min}$.

\section{Hypoglycemic activity of GJ in SIIR rats}

The SIIR rats were divided into 2 groups ( $n=6$ each). The baseline (i.e., $0 \mathrm{~min}$ ) glucose level was checked $30 \mathrm{~min}$ after solution feeding. Another blood glucose sample was drawn $30 \mathrm{~min}$ after the baseline (i.e., $30 \mathrm{~min}$ ).

\section{Insulin and insulin resistance assay}

The concentration of plasma insulin was analyzed by human enzyme-linked immunosorbent assay (Seminariega$\tan$ 29, S-752 28, Mercodia AB, Uppsala, Sweden) in both groups. IR was assessed according to the homeostasis model assessment index calculated using the following formula: (fasting plasma insulin level $[\mu \mathrm{U} / \mathrm{mL}] \times$ fasting plasma glucose $[\mathrm{mmol} / \mathrm{L}]) / 22.5$ [36]; Insulin sensitivity is expressed as insulin sensitivity index (ISI), which was calculated as follows: ISI $=1 /(\log [$ fasting insulin $\mu \mathrm{U} / \mathrm{mL}]+\log [$ fasting glucose $\mathrm{mg} / \mathrm{dL}]$ ) [37]. The results of this experiment are expressed as ISI $\times 10^{3}$.

\section{Western blotting}

At the end of treatment (i.e., $60 \mathrm{~min}$ ) in each group, portions of the gastrocnemius muscles were taken as samples to analyze the insulin signaling proteins, IRS-1 and PPAR $\gamma$. Muscle samples were homogenized in buffer solution before centrifugation at $21,880 \times g$. The supernatants were used to estimate the amount of protein using an assay kit from Bio-Rad Laboratories. The supernatant (i.e., protein) was mixed with $4 \times$ sodium dodecyl sulfate loading dye and boiled for $15 \mathrm{~min}$ at $95^{\circ} \mathrm{C}$ for denaturation. Separating (8\%) and stacking gels were prepared. Protein in buffer $(90 \mu \mathrm{g} / \mathrm{mL})$ was subsequently loaded into each well for electrophoresis. Proteins were electrophoretically transferred to polyvinylidene difluoride membranes at $4^{\circ} \mathrm{C}$. The membranes were then blocked with $5 \%$ nonfat dry milk in phosphate-buffered saline for $1 \mathrm{~h}$ at room temperature and incubated with specific primary antibodies (Santa Cruz Biotechnology, Inc.). After the membranes were washed in buffer containing $0.1 \%$ Tween 20 in $1 \times$ phosphate-buffered saline, the blots were incubated with horseradish peroxidase-linked specific secondary antibody (Santa Cruz Biotechnology, Inc.) and evaluated using an enhanced chemiluminescence detection using ECL Reagent Plus (PerkinElmer Life Sciences, Inc.). Band intensities were quantified by densitometry to observe the target proteins.

\section{Statistical analysis}

The experimental results of all groups are expressed as mean \pm standard error of mean; Student's $t$-test and analysis of variance were performed to determine significance. The level of statistical significance was set at $P<0.05$.

\section{Results}

\section{Optimal dose of GJ for hypoglycemia}

In the normal Wistar rats, plasma glucose levels were checked at 0,30 , and 60 min to determine the hypoglycemic effect in the control and 2 experimental groups (i.e., GJ and GJ 200). The GJ-fed groups exhibited a tendency towards decreasing glucose level with time. The GJ 200 group exhibited a significantly greater hypoglycemic effect than the control and GJ 100 groups.

In the 2 experimental groups, the plasma glucose level of the GJ 100 group did not change significantly until $60 \mathrm{~min}$. Furthermore, the GJ 200 group exhibited significantly decreased plasma glucose levels starting at $30 \mathrm{~min}$. Therefore, we used GJ $200 \mathrm{mg} / \mathrm{kg}$ as the therapeutic dose in subsequent experiments (Table 1). In addition, the hypoglycemic activities (\%) changed in a dose-dependent manner. The GJ 200 group exhibited the best hypoglycemic activity (Figure 1).

\section{Hypoglycemic effect of GJ in SIIR rats}

The SIIR rats exhibited higher serum glucose levels than those of the saline group (Figure 2). The serum glucose levels of SIIR rats fed saline at 0, 30, and $60 \mathrm{~min}$ were $165.1,153.3$, and $153.7 \mathrm{mg} / \mathrm{dL}$, respectively, compared to $165.1,135.5$, and $113.6 \mathrm{mg} / \mathrm{dL}$ in the GJ 200 group of SIIR rats, respectively. There was a significant difference 
Table 1 Plasma glucose changes by group

\begin{tabular}{lccc}
\hline Group & \multicolumn{3}{c}{ Plasma glucose $(\mathbf{m g} / \mathbf{d L})$} \\
\cline { 2 - 4 } & $\mathbf{0} \mathbf{~} \mathbf{i n}$ & $\mathbf{3 0} \mathbf{~} \mathbf{i n}$ & $\mathbf{6 0} \mathbf{~ m i n}$ \\
\hline Saline & $113.45 \pm 13.74$ & $108.28 \pm 11.01$ & $103.35 \pm 11.62$ \\
GJ 100 & $117.46 \pm 6.84$ & $110.05 \pm 7.69$ & $101.28 \pm 5.02^{*}$ \\
GJ 200 & $127.86 \pm 7.74$ & $108.65 \pm 7.95^{*}$ & $99.62 \pm 9.52^{* *}$ \\
\hline
\end{tabular}

GJ: Gardenia jasminoides; GJ 100: feeding GJ 100 mg/kg; GJ 200: feeding GJ $200 \mathrm{mg} / \mathrm{kg}$; saline: feeding normal saline. ${ }^{*} p<0.05,{ }^{* *} p<0.001 \mathrm{vs}$. plasma glucose at $0 \mathrm{~min}$, Student's $t$-test, $n=6$.

between the 2 experimental groups at 60 min (Figure 3a). In addition, the hypoglycemic activity in the GJ 200 group was $17.9 \%$ and $30.8 \%$ at 30 and $60 \mathrm{~min}$, respectively; both results are significantly different from those of the saline group at the corresponding times (Figure $3 b$ ).

\section{Improved insulin sensitivity of SIIR rats after GJ} administration

The SIIR rats treated with GJ $200 \mathrm{mg} / \mathrm{kg}$ exhibited a significant hypoglycemic effect at 30 and $60 \mathrm{~min}$ with no obvious change in insulin level (from 178.92 to 165.77 $\mathrm{mU} / \mathrm{L}$ ) (Table 2). The ISI increased significantly (from 0.67 to 1.05), while the homeostasis model assessment index decreased significantly (from 7.23 to 3.57 ) (Table 2).

\section{Changes in intracellular signaling proteins in SIIR rats after GJ feeding}

Sixty min after feeding GJ $200 \mathrm{mg} / \mathrm{kg}$ to the SIIR rats, the levels of the intracellular signaling proteins, IRS-1 and PPAR $\gamma$, in the skeletal muscular cell were elevated (Figure 4).

\section{Discussion}

The GJ doses of 100 and $200 \mathrm{mg} / \mathrm{kg}$ were chosen on the basis of the study of Kim et al. [33]. GJ $100 \mathrm{mg} / \mathrm{kg}$

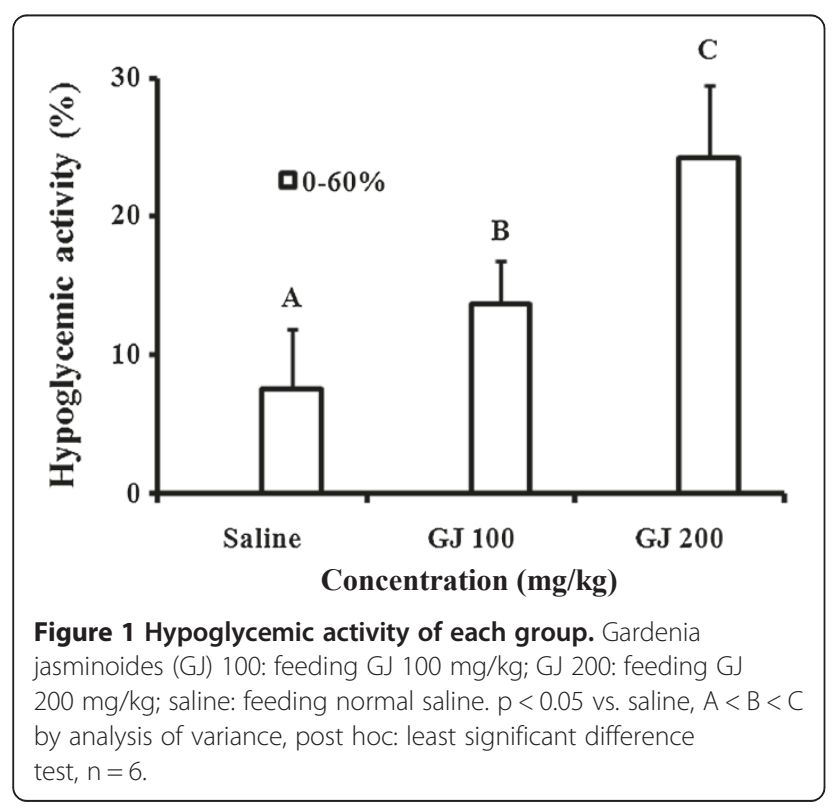

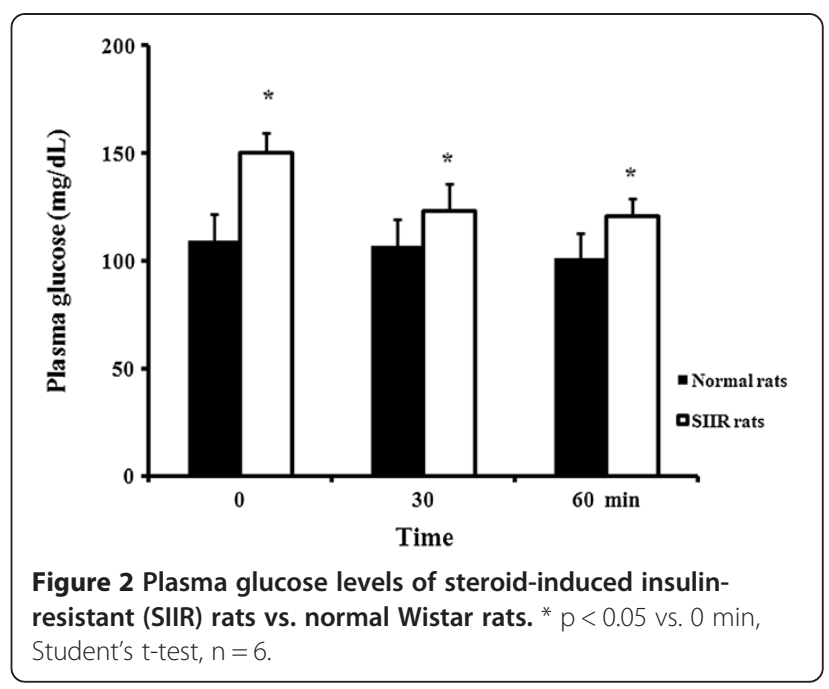

had a hypoglycemic effect at $60 \mathrm{~min}$. However, a significant decrease in plasma glucose levels was observed $30 \mathrm{~min}$ after GJ $200 \mathrm{mg} / \mathrm{kg}$ feeding. Thus, the hypoglycemic effect of GJ $200 \mathrm{mg} / \mathrm{kg}$ was more obvious at $60 \mathrm{~min}$. Therefore, we used the more effective
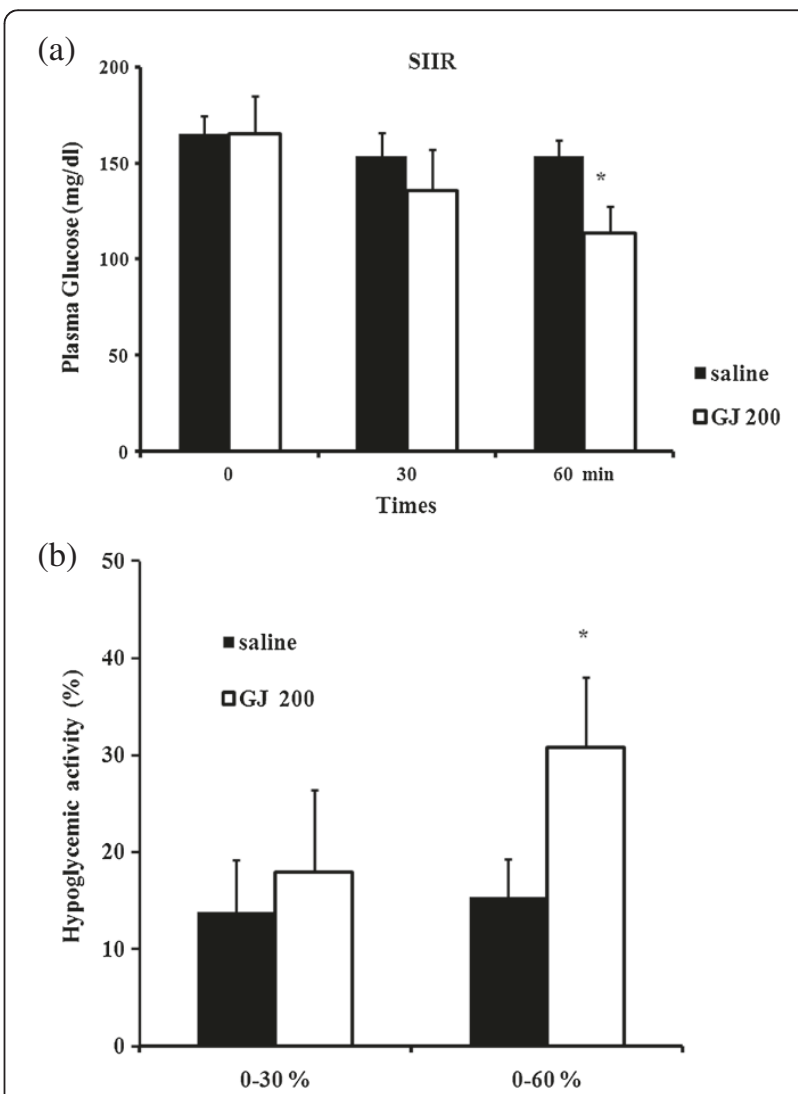

Figure 3 The hypoglycemic effect of GJ in SIIR rats. (a) Plasma glucose level and (b) hypoglycemic activity in the saline and Gardenia jasminoides (GJ) 200 steroid-induced insulin-resistant (SIIR) rats. ${ }^{*} p<0.05$ vs. saline, Student's t-test, $n=6$. 
Table 2 Changes in insulin sensitivity after GJ 200 feeding to SIIR rats

\begin{tabular}{lllll}
\hline & & $\mathbf{0}$ min & 30 $\min$ & $\mathbf{6 0} \mathbf{~ m i n}$ \\
\hline SIIR GJ 200 & Glucose $(\mathrm{mg} / \mathrm{dL})$ & $150.54 \pm 12.84$ & $125.42 \pm 7.59^{*}$ & $105.90 \pm 0.61^{* *}$ \\
$(\mathrm{mg} / \mathrm{kg})$ & Insulin $(\mu \mathrm{U} / \mathrm{mL})$ & $178.92 \pm 17.30$ & $170.07 \pm 17.41$ & $165.77 \pm 25.63$ \\
& ISI $\times 10^{3}$ & $0.67 \pm 0.01$ & $0.85 \pm 0.06^{*}$ & $1.05 \pm 0.18^{*}$ \\
& HOMA & $7.23 \pm 2.0$ & $3.76 \pm 0.72^{*}$ & $3.57 \pm 0.45^{*}$ \\
\hline
\end{tabular}

GJ: Gardenia jasminoides; SIIR: steroid induced insulin resistant; ISI: insulin sensitivity index =1/(log[fasting insulin $\mu \mathrm{U} / \mathrm{mL}]+$ log[fasting glucose $\mathrm{mg} / \mathrm{dL}])$. Results are expressed as ISI $\times 10^{3}$ in this experiment; HOMA: homeostasis model assessment $=($ fasting plasma insulin level $[\mu \mathrm{U} / \mathrm{mL}] \times \mathrm{fasting}$ plasma glucose [mmol/L]) $/ 22.5$. ${ }^{*} p<0.05,{ }^{* *} p<0.005$ vs. 0 min, Student's $t$-test, $n=6$.

dose, GJ $200 \mathrm{mg} / \mathrm{kg}$, in subsequent experiments (Table 1 and Figures 1 and 2).

Dexamethasone is a type of adrenal hormone that has an anti-inflammatory effect. However, it also causes patients with DM to require additional insulin doses and increases IR [38]. In the present study, rats were injected with dexamethasone to induce IR. Dexamethasone can induce gluconeogenesis and increase plasma glucose levels and inhibit insulin secretion. In an animal experiment, steroid therapy decreased the expression of glucose transporter- 2 protein in $\beta$ cells $[39,40]$. Dexamethasone also decreases adenosine monophosphate levels [41] and activates voltage-gated potassium channels [42]. A study reported increased $\beta$-cell apoptosis after corticosteroid receptor activation [38]. Therefore, insulin secretion is inhibited by dexamethasone. These mechanisms are associated with exacerbated DM control and its complications after corticosteroid therapy.

GJ extracts lowered plasma glucose level in the SIIR rats. Several previous studies report that GJ has a hypolipidemic effect. One study reported that lower blood lipid levels are associated with decreased plasma glucose levels [19]. This hypoglycemic mechanism may be due

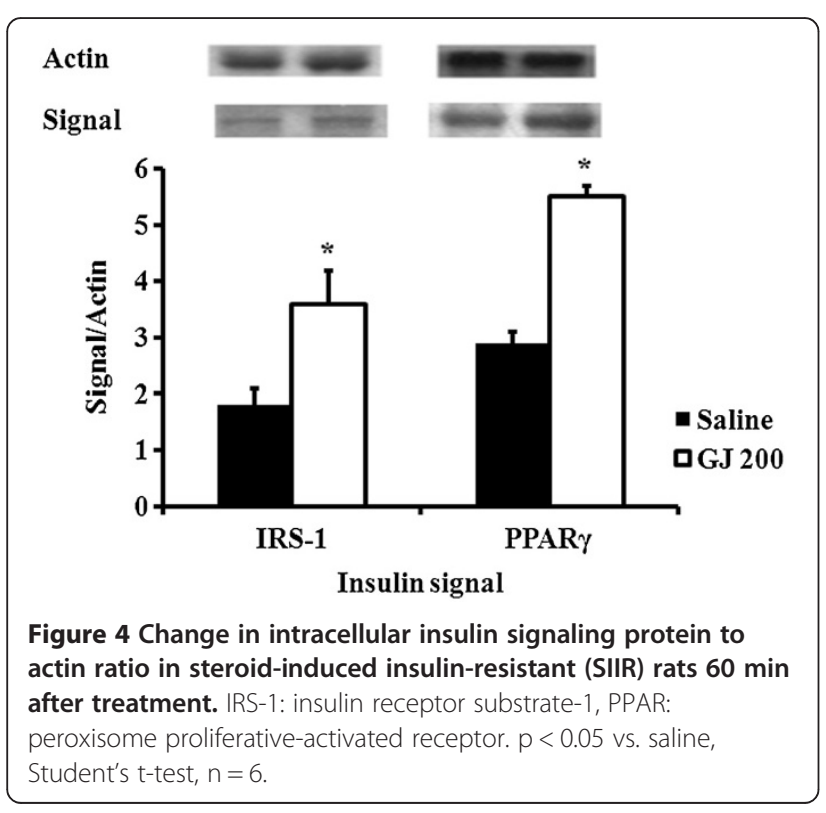

to the improvement of IR or enhancement of signaling proteins in the insulin signaling pathways [19].

A study reports that long-term oral administration of GJ results in a hypolipidemic effect. In other studies, Obesity animals were fed GJ, which exerted a hypolipidemic effect; meanwhile, GJ was fed for 1 to 4 weeks before serum lipid examination in other studies [8]. Since the hypolipidemic effect is beneficial for the action of insulin to lower plasma glucose levels, this is possibly why insulin sensitivity was elevated in the present study. Because of the limitation of this study's design, the 60-min experimental duration was too short to fully observe changes in plasma lipids (unpublished results). The long-term effect of GJ on the relationship between plasma lipids and IR is worth investigating in the future.

IR develops mainly in the liver, skeletal muscle, and adipose tissue. Skeletal muscle cells have difficulty converting plasma glucose into glycogen under IR conditions [43]. In the liver, insulin reduces glycogenolysis and gluconeogenesis [3]. Therefore, the energy of food can be stored, keeping plasma glucose within the normal range. However, when IR develops, such homeostasis is blocked and hyperglycemia is not preventable [44]. In the experiment analyzing changes in intracellular insulin signaling proteins in SIIR rats, PPAR $\gamma$ signaling was augmented after GJ feeding (Figure 4). This hypoglycemic mechanism is similar to that observed with thiazolidinediones.

The main hypoglycemic mechanism of thiazolidinediones occurs in adipose tissue, enhancing free fatty acid uptake by adipocytes [45]. Thiazolidinediones can also lower serum triglyceride and non-esterified fatty acids. PPAR $\gamma$ activation also induces adipocyte differentiation and decreases glucose release from the liver, enhancing glycogen storage in skeletal muscle cells [40]. Since the hypoglycemic effect of GJ is similar to that of thiazolidinediones, GJ may be able to induce insulin sensitivity and prevent DM development. Thus, GJ has the potential to be used as an insulin sensitizer and even as a substitute for thiazolidinediones [19].

\section{Conclusions}

In conclusion, improvement of IR can effectively lower plasma glucose and prevent hyperinsulinemia and/or lower the required doses of oral anti-diabetes agents. 
Thiazolidinediones effectively decrease IR, but their side effects limit their clinical application [28-30]. Although the hypoglycemic effect of GJ is similar to that of thiazolidinediones, it is possible that GJ will not cause similar side effects in clinical therapy. Therefore, GJ is a potential insulin-sensitizing agent for patients with type $2 \mathrm{DM}$ and/or adjuvant therapy $[19,20]$.

\section{Abbreviations}

DM: Diabetes mellitus; GJ: Gardenia jasminoides; ISI: Insulin sensitivity index; PPAR: Peroxisome proliferator-activated receptor; SIIR: Steroid-induced insulin-resistant.

\section{Competing interests}

The authors declare that they have no competing interests.

\section{Authors' contributions}

YIC, YWC and JCC drafted the manuscript, and acquired and analyzed data. CYT and YCL assisted with the acquisition of funding and provided the research environment. YIC managed the execution of the experiments and animal models. SCL, YNC, and CCT have supervised and monitored the execution of this study. TCT and SLC made substantial contributions to the study concept, study design, and critical revision of the manuscript's important intellectual content and submitted the manuscript for publication. All authors read and approved the final manuscript.

\section{Acknowledgements}

We thank the National Science Council of Taiwan (NSC101-2320-B-212-001MY2, NSC101-2632-E-212-001-MY3) and Taichung Veterans General Hospital and Da-Yeh University joint project (TCVGH-DYU-1018303) for funding this research. We also thank Miss Xin-Ping Ku for her assistance.

\section{Author details}

'Graduate Institute of Biotechnology, National Chung Hsing University, Taichung, Taiwan. ${ }^{2}$ College of Life Sciences, National Tsing Hua University, Hsinchu, Taiwan. ${ }^{3}$ Department of Internal Medicine, Lee's General Hospital, Miaoli, Taiwan. ${ }^{4}$ Department of Orthopedics, Taichung Veterans General Hospital, Taichung City, Taiwan. ${ }^{5}$ Department of Acupuncture, China Medical University Hospital and School of Chinese Medicine, China Medical University, Taichung, Taiwan. 'Department of Biotechnology, National Formosa University, Yunlin County, Taiwan. ${ }^{7}$ Department of Biolndustry technology, Da-Yeh University, Changhua County, Taiwan. ${ }^{8}$ Chinese Medicine Department E-D Hospital, I-Shou University, Kaohsiung, Taiwan. ${ }^{9}$ School of Chinese Medicine for Post-Baccalaureate, I-Shou University, Kaohsiung, Taiwan. ${ }^{10}$ Department of Medicinal Botanicals and Health Applications, Da-Yeh University, Changhua, Taiwan.

Received: 30 September 2013 Accepted: 15 January 2014 Published: 18 January 2014

\section{References}

1. Zafiriou S, Stanners SR, Saad S, Polhill TS, Poronnik P, Pollock CA: Pioglitazone inhibits cell growth and reduces matrix production in human kidney fibroblasts. J Am Soc Nephrol 2005, 16(3):638-645.

2. Arkan MC, Hevener AL, Greten FR, Maeda S, Li ZW, Long JM, Wynshaw-Boris A, Poli G, Olefsky J, Karin M: IKK-beta links inflammation to obesityinduced insulin resistance. Nat Med 2005, 11(2):191-198.

3. Kovacs P, Stumvoll M: Fatty acids and insulin resistance in muscle and liver. Best Pract Res Clin Endocrinol Metab 2005, 19(4):625-635.

4. Dresner A, Laurent D, Marcucci M, Griffin ME, Dufour S, Cline GW, Slezak LA, Andersen DK, Hundal RS, Rothman DL, et al: Effects of free fatty acids on glucose transport and IRS-1-associated phosphatidylinositol 3-kinase activity. J Clin Invest 1999, 103(2):253-259.

5. Ghazzi MN, Perez JE, Antonucci TK, Driscoll JH, Huang SM, Faja BW, Whitcomb RW: Cardiac and glycemic benefits of troglitazone treatment in NIDDM. The Troglitazone Study Group. Diabetes 1997, 46(3):433-439.

6. Bastarrachea RA, Lopez-Alvarenga JC, Bolado-Garcia VE, Tellez-Mendoza J, Laviada-Molina H, Comuzzie AG: Macrophages, inflammation, adipose tissue, obesity and insulin resistance. Gac Med Mex 2007, 143(6):505-512.
7. Yuan M, Konstantopoulos N, Lee J, Hansen L, Li ZW, Karin M, Shoelson SE: Reversal of obesity- and diet-induced insulin resistance with salicylates or targeted disruption of Ikkbeta. Science 2001, 293(5535):1673-1677.

8. Boden $\mathrm{G}$, Laakso M: Lipids and glucose in type 2 diabetes: what is the cause and effect? Diabetes Care 2004, 27(9):2253-2259.

9. DeFronzo RA, Ferrannini E: Insulin resistance. A multifaceted syndrome responsible for NIDDM, obesity, hypertension, dyslipidemia, and atherosclerotic cardiovascular disease. Diabetes Care 1991, 14(3):173-194.

10. Liu Z, Fu C, Wang W, Xu B: Prevalence of chronic complications of type 2 diabetes mellitus in outpatients - a cross-sectional hospital based survey in urban China. Health Qual Life Outcomes 2010, 8:62.

11. Bailey CJ, Day C: Avandamet: combined metformin-rosiglitazone treatment for insulin resistance in type 2 diabetes. Int J Clin Pract 2004, 58(9):867-876

12. Bakris G, Viberti G, Weston WM, Heise M, Porter LE, Freed MI: Rosiglitazone reduces urinary albumin excretion in type II diabetes. J Hum Hypertens 2003, 17(1):7-12.

13. Bell DS: Beneficial effects resulting from thiazolidinediones for treatment of type 2 diabetes mellitus. Postgrad Med 2003, Spec No:35-44.

14. DeFronzo RA, Goodman AM: Efficacy of metformin in patients with noninsulin-dependent diabetes mellitus. The Multicenter Metformin Study Group. N Engl J Med 1995, 333(9):541-549.

15. Einhorn D, Rendell M, Rosenzweig J, Egan JW, Mathisen AL, Schneider RL: Pioglitazone hydrochloride in combination with metformin in the treatment of type 2 diabetes mellitus: a randomized, placebo-controlled study. The Pioglitazone 027 Study Group. Clin Ther 2000, 22(12):1395-1409.

16. Maggs DG, Buchanan TA, Burant CF, Cline G, Gumbiner B, Hsueh WA, Inzucchi S, Kelley D, Nolan J, Olefsky JM, et al: Metabolic effects of troglitazone monotherapy in type 2 diabetes mellitus. A randomized, double-blind, placebo-controlled trial. Ann Intern Med 1998, 128(3):176-185.

17. Boyle PJ, King AB, Olansky L, Marchetti A, Lau H, Magar R, Martin J: Effects of pioglitazone and rosiglitazone on blood lipid levels and glycemic control in patients with type 2 diabetes mellitus: a retrospective review of randomly selected medical records. Clin Ther 2002, 24(3):378-396.

18. Fan C, Li Q, Zhang Y, Liu X, Luo M, Abbott D, Zhou W, Engelhardt JF: IkappaBalpha and lkappaBbeta possess injury context-specific functions that uniquely influence hepatic NF-kappaB induction and inflammation. J Clin Invest 2004, 113(5):746-755.

19. Zhang $C Y$, Parton $L E$, Ye CP, Krauss $S$, Shen R, Lin CT, Porco JA Jr, Lowell BB: Genipin inhibits UCP2-mediated proton leak and acutely reverses obesity- and high glucose-induced beta cell dysfunction in isolated pancreatic islets. Cell Metab 2006, 3(6):417-427.

20. Sheng L, Qian Z, Zheng S, Xi L: Mechanism of hypolipidemic effect of crocin in rats: crocin inhibits pancreatic lipase. Eur J Pharmacol 2006, 543(1-3):116-122.

21. Herder C, Schneitler S, Rathmann W, Haastert B, Schneitler H, Winkler H, Bredahl R, Hahnloser E, Martin S: Low-grade inflammation, obesity, and insulin resistance in adolescents. J Clin Endocrinol Metab 2007, 92(12):4569-4574.

22. Shulman Gl: Cellular mechanisms of insulin resistance. J Clin Invest 2000, 106(2):171-176.

23. Hotamisligil GS: Inflammation and metabolic disorders. Nature 2006, 444(7121):860-867.

24. Del Prato S, Volpe L: Rosiglitazone plus metformin: combination therapy for Type 2 diabetes. Expert Opin Pharmacother 2004, 5(6):1411-1422.

25. Marcy TR, Britton ML, Blevins SM: Second-generation thiazolidinediones and hepatotoxicity. Ann Pharmacother 2004, 38(9):1419-1423.

26. Fukuen S, Iwaki M, Yasui A, Makishima M, Matsuda M, Shimomura I: Sulfonylurea agents exhibit peroxisome proliferator-activated receptor gamma agonistic activity. J Biol Chem 2005, 280(25):23653-23659.

27. Yue TL: Cardioprotective effects of thiazolidinediones, peroxisome proliferator-activated receptor-gamma agonists. Drugs Today (Barc) 2003, 39(12):949-960.

28. Goldstein BJ, Cobitz AR, Hand LM, Chen H: Are the metabolic effects of rosiglitazone influenced by baseline glycaemic control? Curr Med Res Opin 2003, 19(3):192-199.

29. Kermani A, Garg A: Thiazolidinedione-associated congestive heart failure and pulmonary edema. Mayo Clin Proc 2003, 78(9):1088-1091.

30. Lin EH, Katon W, Von Korff M, Rutter C, Simon GE, Oliver M, Ciechanowski P, Ludman EJ, Bush T, Young B: Relationship of depression and diabetes 
self-care, medication adherence, and preventive care. Diabetes Care 2004, 27(9):2154-2160

31. Knowler WC, Barrett-Connor E, Fowler SE, Hamman RF, Lachin JM, Walker EA, Nathan DM: Reduction in the incidence of type 2 diabetes with lifestyle intervention or metformin. N Engl J Med 2002, 346(6):393-403.

32. Scheen AJ: Combined thiazolidinedione-insulin therapy: should we be concerned about safety? Drug Saf 2004, 27(12):841-856.

33. Zhou J, Huang K: Peroxynitrite mediates muscle insulin resistance in mice via nitration of IRbeta/IRS-1 and Akt. Toxicol Appl Pharmacol 2009, 241(1):101-110.

34. Elias JM, Gown AM, Nakamura RM, Wilbur DC, Herman GE, Jaffe ES, Battifora $H$, Brigati DJ: Quality control in immunohistochemistry. Report of a workshop sponsored by the Biological Stain Commission. Am J Clin Pathol 1989, 92(6):836-843.

35. Xu YP, Liang L, Wang XM: The levels of Pdx1/insulin, Cacna1c and Cacna1d and beta-cell mass in a rat model of intrauterine undernutrition. J Matern Fetal Neonatal Med 2011, 24(3):437-443.

36. Salgado AL, Carvalho L, Oliveira AC, Santos VN, Vieira JG, Parise ER: Insulin resistance index (HOMA-IR) in the differentiation of patients with non-alcoholic fatty liver disease and healthy individuals. Arq Gastroenterol 2010, 47(2):165-169.

37. Retnakaran R: The insulin secretion-sensitivity index-2 (ISSI-2) and the measurement of beta-cell function in women with gestational diabetes. Endocr I 2010, 57(11):1007. author reply 1009-1010.

38. Ranta F, Avram D, Berchtold S, Dufer M, Drews G, Lang F, Ullrich S: Dexamethasone induces cell death in insulin-secreting cells, an effect reversed by exendin-4. Diabetes 2006, 55(5):1380-1390.

39. Ohneda M, Johnson JH, Inman LR, Unger RH: GLUT-2 function in glucoseunresponsive beta cells of dexamethasone-induced diabetes in rats. J Clin Invest 1993, 92(4):1950-1956.

40. Gremlich S, Roduit $R$, Thorens B: Dexamethasone induces posttranslational degradation of GLUT2 and inhibition of insulin secretion in isolated pancreatic beta cells. Comparison with the effects of fatty acids. J Biol Chem 1997, 272(6):3216-3222.

41. Philippe J, Giordano E, Gjinovci A, Meda P: Cyclic adenosine monophosphate prevents the glucocorticoid-mediated inhibition of insulin gene expression in rodent islet cells. J Clin Invest 1992, 90(6):2228-2233

42. Ullrich S, Berchtold S, Ranta F, Seebohm G, Henke G, Lupescu A, Mack AF, Chao CM, Su J, Nitschke R, et al: Serum- and glucocorticoid-inducible kinase 1 (SGK1) mediates glucocorticoid-induced inhibition of insulin secretion. Diabetes 2005, 54(4):1090-1099.

43. Kruszynska YT, Mukherjee R, Jow L, Dana S, Paterniti JR, Olefsky JM: Skeletal muscle peroxisome proliferator- activated receptor-gamma expression in obesity and non- insulin-dependent diabetes mellitus. J Clin Invest 1998, 101(3):543-548.

44. Antuna-Puente B, Feve B, Fellahi S, Bastard JP: Obesity, inflammation and insulin resistance: which role for adipokines. Therapie 2007, 62(4):285-292.

45. Takashima T, Fujiwara Y, Higuchi K, Arakawa T, Yano Y, Hasuma T, Otani S: PPARgamma ligands inhibit growth of human esophageal adenocarcinoma cells through induction of apoptosis, cell cycle arrest and reduction of ornithine decarboxylase activity. Int J Oncol 2001, 19(3):465-471.

doi:10.1186/1472-6882-14-30

Cite this article as: Chen et al:: Peroxisome proliferator-activated receptor activating hypoglycemic effect of Gardenia jasminoides Ellis aqueous extract and improvement of insulin sensitivity in steroid induced insulin resistant rats. BMC Complementary and Alternative Medicine 2014 14:30.

\section{Submit your next manuscript to BioMed Central and take full advantage of:}

- Convenient online submission

- Thorough peer review

- No space constraints or color figure charges

- Immediate publication on acceptance

- Inclusion in PubMed, CAS, Scopus and Google Scholar

- Research which is freely available for redistribution

Submit your manuscript at www.biomedcentral.com/submit
Ciomed Central 